\title{
Does feudalism have a role in 21 st century land law?
}

by Charles Harpum

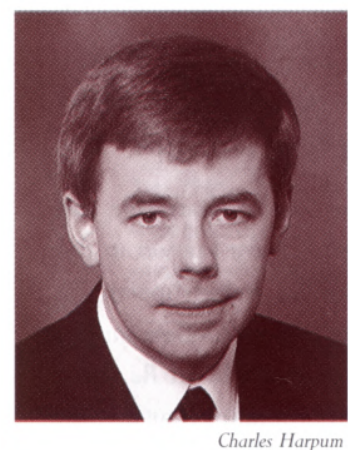

$\mathrm{T}$ here is before the Scottish Parliament in Edinburgh at present a very important Bill, the Abolition of Feudal Tenure etc. (Scotland) Bill. It is intended to implement the Scottish Law Commission's 'Report on Abolition of the Feudal System' ((1999) Scot Law Com No. 168). It is largely the work of Professor Ken Reid, who has responsibility for property law at the Scottish Law Commission. As the title of the Bill suggests, it will abolish the feudal system as it applies in Scotland. The thesis of this article is that an equivalent piece of legislation is needed for England and Wales, though for rather different reasons. It begins with an explanation of what remains of feudalism in English law. This remnant has absolutely no connection whatever with the logic of feudalism as it developed, and cannot be justified. Many lawyers consider that the surviving aspects of feudalism are quaint and harmless relics from the past and should be left alone. In fact, as this article attempts to demonstrate, what remains of feudalism does no good and a great deal of harm. It is concerned with the two main relics of feudalism - the Crown's ultimate residual 'paramount lordship' and the doctrine of escheat. There is no attempt to engage in a scholarly discourse on the nature of either. It is enough to set out the principal elements of the law, which have been drawn from the standard sources (such as Challis).

\section{THE CROWN'S PARAMOUNT LORDSHIP}

As Lord Coke explained in his celebrated Commentary on Littleton's Tenures (1628):

'all the lands within this realm were originally derived from the crown, and therefore, the king is sovereign, or lord paramount, either mediate or immediate, of all and every parcel of land within the realm. (Co Litt 65a)

Originally, there was a 'feudal pyramid' in this country. In other words, all land was vested in the king who granted land to his tenants in chief in return for services - a process called 'infeudation'. Those tenants in chief in turn made subinfeudatory grants to their followers in exchange for services, and those followers further subinfeudated, and so on. Lords further down the feudal pyramid were called 'mesne' or intermediate lords. In other words, the only way of disposing of land was to grant it in return for services. The statute Quia Emptores 1290, which is still on the statute book, abolished the practice of subinfeudation. It prohibits feudal grants to tenants in fee simple in exchange for services. The only way in which freehold land could thereafter be transferred was by a substitutionary grant. Thus if A was B's feudal tenant, and wanted to transfer land to $\mathrm{C}$, he could no longer subinfeudate to $C$, creating another rung in the feudal ladder. Instead, $C$ would be substituted for A as B's feudal tenant. The statute Quia Emptores did not bind the Crown. It could not, because the Crown could not transfer its paramount lordship to anybody. All it could do was to grant a fee simple by way of an infeudatory grant from its paramount ownership. That remains the case today, though any such grantee will not now do homage and services for the land granted to him, but pay hard cash for it. Most of the vestiges of feudalism were finally swept away by the Tenures Abolition Act 1660.

The consequences of this are explained in a well-known textbook as follows:

'After 1290 the feudal pyramid began to crumble. The number of mesne lordships could not be increased, evidence of existing mesne lordships gradually disappeared with the passage of time, and so most land came to be held directly from the Crown.' (Megarry \& Wade's Law of Real Property, 6th edn, 2000, 2-043)

There is now a strong presumption that every frecholder holds his land directly of the Crown as its tenant in chief. In 1832, the Real Property Commissioners, in their Third Report on Real Property, commented that 'land is now most usually held immediately of the Crown'. By 1973, the Court of Appeal considered that:

'the possibility of the emergence of the mesne lord ... is one that is so remote that it may be wholly ignored for present purposes'. (Re Lowe's WT [1973] 1 WLR 882,886, per Russell LJ) 
However, the theoretical possibility of the existence of a mesne lord may explain why the Crown can own a freehold estate in land as well as having its paramount lordship. The frechold does not merge in the Crown's higher right. However, it is very questionable whether the Crown could grant to itself a fee simple out of its paramount lordship. It is not easy to see how the Crown, one and indivisible as it is, can hold land as tenant in chief of itself (see the Scmlla case, as above, 801). That point is not, as it happens, one that is entirely academic. There are two cases where the existence of a mesne lordship is genuine. Those who own freeholds within one or other of the two royal Duchies of Cornwall and Lancaster hold them respectively of the Duke of Cornwall and of the Crown in right of the Duchy of Lancaster.

There is one curiosity about the Crown's paramount lordship. It has no generally accepted name in English law, though it has been called 'absolute property' (Real Property Commissioners, Third Report on Real Property (1832), p. 3) or 'dominium directum' (sec Attorney-General of Ontario $v$ Mercer (1883) 8 App Cas 767,772 , referring to Co Litt 1a, 1b). It is also rather a curious form of ownership. As explained below, it is an ownership that can be without responsibility. One point that does need to be stressed is that the Crown's lordship is not an estate in land. English law developed, almost by accident, the doctrine of estates, that is, the idea that ownership in land can be divisible in time. The owner of an estate is not the owner of the land. He does not have dominium directum. He merely owns the right to enjoy the land for a period of time. Even the largest estate - the fee simple absolute - may come to an end. Indeed it is that fact that underlies this article.

\section{ESCHEAT}

\section{What is escheat?}

If circumstances occur where there is no longer any feudal tenant, the land returns, by reason of tenure, to the feudal lord who created the tenure (Attorney-General of Ontario v Mercer, cited above, at 772). Escheat is the name given to this process by which the land reverts to the tenant's lord. As indicated above, outside the two royal Duchies, there is a presumption that a fee simple owner holds his land directly of the Crown and not of some intermediate lord. It follows that where escheat occurs, the tenant's fee simple ends. If he held that fee simple in either of the royal Duchies, the land will still be held in fee simple, but it will be the prior fee simple of the mesne lord, the Duke of Cornwall or the Crown in right of the Duchy of Lancaster (as the case may be). If, however, the tenant had held in fee simple of the Crown, the Crown holds the land in its paramount lordship. In each case, what has happened is the removal of one tier from the feudal pyramid. If the Crown subsequently grants that land afresh, it will do so by an infeudatory grant in fee simple. It is assumed that neither of the royal Duchies can make infeudatory grants. If they sell land that had escheated to them, presumably they do so by substitutionary grant instead. If that is correct, what would happen if that land were, once again, to escheat. Would it this time escheat to the Crown?

Escheat is only completed when the lord to whom it reverts either enters on the land or takes proceedings to recover it. At one time it was necessary for there to be an inquisition before an escheat could take place. Indeed the Crown employed an 'escheator' in every county to enforce its rights. Such inquisitions have long been obsolete and were formally abolished by the Crown Estate Act 1961, s. 8(4).

There is one other curiosity about escheat that should be mentioned at this stage. For nearly 500 years, there was a view, based on a dictum in Prior of Spalding's Case of 1467 that was cited in Coke on Littleton (Co Litt 13b), that the doctrine of escheat did not apply to a corporation. If a corporation was dissolved, any lands which it held reverted to the grantor. As Blackstone explained in his Commentaries:

the law doth annex a condition to every such grant, that if the corporation be dissolved, the grantor shall have the lands again, because the cause of the grant faileth.'

This view must have been based on the sort of charitable and eleemosynary corporations that Coke would have known in the early 17 th century, because it seems oddly inappropriate in relation to joint stock companies. It did not receive its quietus until the decision of the Court of Appeal in 1933 in Re Wells. Ironically, it is in the context of insolvent companies that the last vestiges of feudalism are causing the most difficulty. This is explained below.

\section{When does escheat occur?}

At one time the situations in which escheat occurred were fairly common. Tivo were of particular importance:

(1) Where a person was convicted of any felony other than treason; in cases of treason there was forfeiture to the Crown rather than escheat to the traitor's lord. Both this particular form of escheat and forfeiture were abolished by the Forfeiture Act 1870.

(2) An estate escheated if the owner died intestate and without heirs. This was abolished by the Administration of Estates Act, which made provision for the land to pass to the Crown or (where relevant) the Duchy of Cornwall or the Duchy of Lancaster as bona vacantia in lieu of any right to escheat. In such a case, the Crown (or Duchy) takes directly under the statutory provisions of the 1925 Act and not by any prerogative right (Re Mitchell [1954] Ch 525).

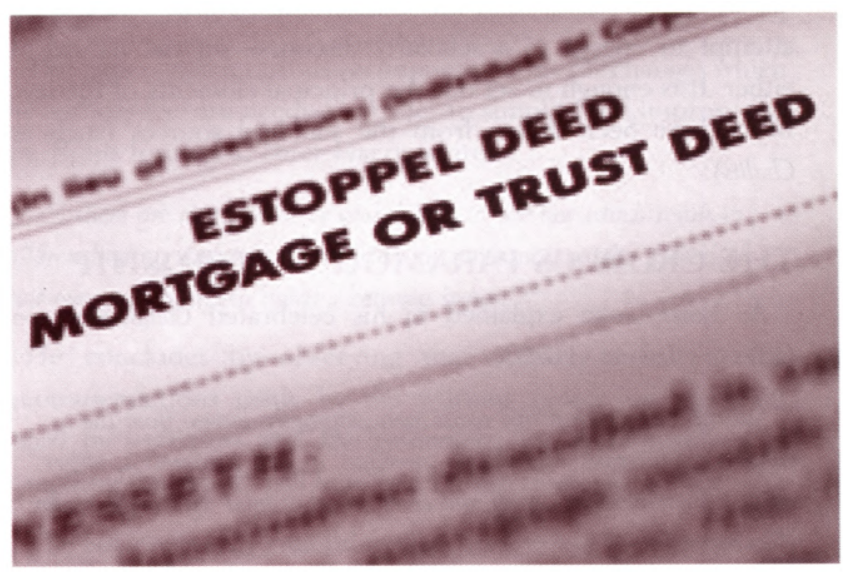

Although both the principal instances of escheat have now gone, it can still occur in a number of cases. All are associated with insolvency, and they have a history that goes back to the Bankruptcy Act 1869. Where a freehold is disclaimed, there is 
necessarily an escheat, and this is now firmly established by a line of authority going back to Re Mercer and Moore in 1880. It was restated most recently in 1995 by Stanley Burnton QC, sitting as a Deputy High Court Judge, in the leading modern case, Scmlla Properties Ltd v Gesso Properties (BVI) Ltd [1995] BCC 793. There are three circunstances in which a freehold may be disclaimed:

(1) A trustee in bankruptcy may disclaim onerous property under s. 315 of the Insolvency Act 1986. Onerous property is defined as 'any unprofitable contract' and 'any other property comprised in the bankrupt's estate which is unsaleable or not readily saleable, or is such that it may give rise to a liability to pay money or perform any other onerous act'.

(2) There is an analogous provision in s. 178 of the Insolvency Act 1986, by which a liquidator of a company that is being wound up may disclaim onerous property. Onerous property is defined in the same way.

(3) Under s. 654 of the Companies Act 1985, when a company is dissolved, all its property vests in the Crown or the Duchy of Cornwall or Lancaster as bona vacantia. However, s. 656 of the same Act permits the Crown, by means of a notice issued by the Treasury Solicitor (or relevant Duchy official) within 12 months of the date on which the company's property vested in it, to disclaim any such property. The effect of this is, of course, that, in the case of frechold land, the property then becomes ownerless and promptly escheats to the Crown. So what the Crown disclaims as bona vacantia it promptly reacquires by way of escheat! These two provisions of the Companies Act 1985 are not new. They replicate equivalent sections in the Companies Act 1948. This rather curious result has been the subject of comment, both academic and judicial. In the Scmlla case (as above, 805), Stanley Burnton QC remarked that that it was 'difficult to see the object of these provisions in so far as they concern freeholds'

There may in fact be a very good reason for the provision. It appears that the liability of the Crown for land that it receives as bona vacantia may be much more stringent than its liability for property that passes to it by way of escheat. When property passes to the Crown, whether as bona vacantia or by escheat, it is not freed from the burdens that bound it previously. This is indeed well settled by authority (see, e.g. Attorney-General of Ontario v Mercer and Scmlla Properties Ltd v Gesso Properties (BVI) Ltd, as above) and is discussed further below. As will be apparent from what has been said, in most cases of escheat, the very reason why the property ends up in the hands of the Crown is because it is onerous and has therefore been disclaimed on the insolvency of a company or the bankruptcy of an individual. Curiously, the Crown's responsibility for property which passes to it as bona vacantia has never been definitively determined. However, in Toff $v$ McDowell (1993) 69 P \& CR 535 it was assumed without argument that, where a freehold reversion on a lease vested in the Crown as bona vacantia, the Crown was subject to the burden of the covenants of that lease. In that casc the company which owned the reversion had been struck off the Register of Companies, and the Crown had not disclaimed the lease within 12 months under s. 656 of the Companies Act 1985. On the facts, the Crown was not liable anyway. It should be noted that where property passes to the Crown as bona vacantia, it acquires the very estate which is subject to the burdens.

The position should be contrasted with a case of escheat. First, the freehold estate does not vest in the Crown: it is extinguished. Secondly, it has been accepted that the Crown is not liable provided that it does not enter and manage the property (see, e.g. Scmlla Properties Ltd v Gesso Properties (BVI) Ltd, above, at 804, 805; Re Nottingham General Cemetery Co [1955] Ch 683; Attorney-General v Parsons [1956] AC 421). This is consistent with s. 40(4) of the Crown Proceedings Act 1947, which protects the Crown from any liability in tort in cases where property vests in it by virtue of any rule of law. That principle does not apply where it takes control of the property or enters into occupation of it.

\section{PARADOX}

There is an element of paradox in the present position. Most of the cases of escheat arise out of insolvent companies. ... for nearly 500 years prior to 1933 , it was thought that escheat had no application to corporations. Now it applies almost exclusively to corporations. Corporations are not, of course, institutions for which the feudal system was devised.

The assumption made in Toff $v$ McDowell that the Crown is liable for property it receives as bona vacantia but fails to disclaim may or may not be correct. However, the existence of that assumption may explain why, under s. 656 of the Companies Act 1985, the Treasury Solicitor can disclaim land received by the Crown as bona vacantia so that it can then escheat to the Crown. In practice, it is understood that this is precisely why, in any case of doubt, the Treasury Solicitor does now disclaim any property received as bona vacantia that may be onerous. The Treasury Solicitor's practice explains why there has been a sharp rise in the number of escheats of freehold. In 1995, there were 200 such escheats every year. It may now be significantly more than that, though this impression is anecdotal and has not been verified.

There is an element of paradox in the present position. Most of the cases of escheat arise out of insolvent companies. As mentioned earlier, for nearly 500 years prior to 1933, it was thought that escheat had no application to corporations. Now it applies almost exclusively to corporations. Corporations are not, of course, institutions for which the feudal system was devised. However, paradox alone does not justify a change to the law. What are the consequences of the retention of the Crown's paramount lordship and of escheat, and why is reform of the law desirable?

\section{SOME AWKWARD CONSEQUENCES}

The significant number of escheats has thrown into sharp relief the problems to which the doctrine and the existence of the Crown's paramount lordship give rise. Some of these difficulties are explained below

The first is a problem that led the present author to explore this arcane area of the law in the first place. For some years the Law Commission and HM Land Registry have been working together to produce a new Land Registration Act that will replace the existing legislation and create a system of land 
registration built round electronic conveyancing. The Crown has considerable amounts of land which it holds in paramount lordship. Perhaps the largest such area is the foreshore around the coast of England and Wales. As the law stands, the Crown cannot register any land which it holds in paramount lordship. This is because only an estate in land can be registered under the Land Registration Act 1925. In the Scmlla case, Stanley Burnton QC referred to this 'major, but unremarked, lacuna in the system of land registration'. This lacuna has not gone unremarked at HM Land Registry and it is worth spelling out its consequences. First, the Crown cannot apply for the registration of the title to the land which it holds in paramount lordship. This would not matter if it could grant to itself a fee simple, which it could then register. However, as has already been explained, the Crown probably cannot do that. This is because it cannot be both lord and tenant in chief. Secondly, when registered land escheats, whether to the Crown or to one of the Duchies, the title has to be closed and the land removed from the register. This is because the registered freehold no longer exists. At a time when the Registry is seeking to ensure that all land in England and Wales is registered, this is galling. It is also nonsensical. The Law Commission and the Land Registry have been in negotiation with the Crown for a considerable time to try to resolve these matters. However, any solutions are necessarily limited by the fact that our reforms are confined to registered land. We cannot abolish the feudal system.

\section{DOCTRINE OF ESTATES}

One point that does need to be stressed is that the Crown's lordship is not an estate in land. English law developed, almost by accident, the doctrine of estates, that is, the idea that ownership in land can be divisible in time. The owner of an estate is not the owner of the land. He does not have dominium directum. He merely owns the right to enjoy the land for a period of time. Even the largest estate - the fee simple absolute - may come to an end.

Secondly, the present law gives rise to some very difficult problems in practice. This may be illustrated by two cases, both decided in 1995.

The first is the leading modern decision on escheat, Scmlla Properties Ltd ${ }_{V}$ Gesso Properties (BVI) Ltd. A company called Grantborough Ltd was the landlord of a block of flats in Maida Vale. It had mortgaged its reversionary interest in the building. Grantborough went into insolvent liquidation, and the liquidator disclaimed the freehold. Some months later, the mortgagee, purporting to exercise its power of sale, entered into a contract to sell the land to the defendant. The issue before the court was whether this sale was a disposal of the kind that triggered the tenants' right to nominate a purchaser - in this case the plaintiff company - to whom the new landlord was required to sell his reversion under the provisions of the Landlord and Tenant Act 1987. Stanley Burnton QC, sitting as a Deputy High Court Judge, delivered a very scholarly judgment, holding that the sale by the mortgagee did trigger the provisions of the 1987 Act. It is necessary to look in some detail at this judgment. The judge began with remarks that are highly pertinent:

'I was initially amused, but ultimately dismayed, that the rights of the parties under a modern statute reforming the law of landlord and tenant should depend on the vestiges of feudal land law. My dismay grew as it became apparent that my decision in this case involved an examination of fundamental concepts of our land law, and an examination of concepts and authorities dating back several centuries.

There were five main elements in his judgment, the first three of which have already been touched on:

(1) He held that the disclaimer terminated Grantborough's freehold interest.

(2) That disclaimer led to the escheat of the freehold estate to the Crown and that escheat occurred automatically. There was no tenant of the freehold, so that the Crown's paramount lordship was, as the judge put it, 'no longer encumbered by the freehold interest'. Furthermore, and following from this, the Crown did, not by escheat alone, assume the liabilities of the freeholder. It was not a successor in title to the former freeholder.

(3) Although the frechold estate was determined, the subordinate interests in that freehold estate, such as the mortgage affecting it and the leases granted out of it, were not determined. This was so, even though, as the judge admitted, 'it is ... difficult to understand how a subordinate interest, created out of a freehold, can survive the termination of the freehold interest'. The Crown did not, however, become subject to any personal obligation to pay the mortgage debt, because, as explained, it did not assume the liabilities of the former frecholder. These first three points seem correct in principle and accord with the weight of previous authority.

(4) The fourth point in the judgment is more difficult. The judge went on to hold that the mortgagee had power to sell the land subject to the mortgage, that it had done so, and that the sale had vested a fee simple in the defendant purchaser. This is a convenient conclusion, but one that can only be reached by a most circuitous route. The relevant provisions of the Law of Property Act 1925 which confer on the mortgagee a power of sale, assume quite reasonably that he will convey the estate bound by the mortgage. But where there has been an escheat, that estate has disappeared. There are two alternatives therefore, neither of them satisfactory. First, the fee simple that was extinguished by the escheat revives when the mortgagee exercises its power of sale. That was in fact the view favoured by Deputy Judge Burnton. If that is correct, it leads to at least one odd consequence. If the title to the freehold was registered, it should be removed from the register on escheat. If, however, by exercising its power of sale, a mortgagee causes that extinguished freehold to revive, then presumably the title to it has to be reinstated on the register with the same title number as it had previously. The second alternative is that, by exercising its power of sale, the mortgagee brings about an infeudatory grant of a new freehold from the Crown to the purchaser, even though the Crown is not a party to that transaction. That does of course look very strange, but it is arguably a more logical cxplanation than that of revival. If correct, it means that the purchaser acquires a wholly new title, but presumably subject to any encumbrances that bound the former freehold that were not overreached by the mortgagee's sale. It goes without saying that if the land had 
not escheated, but had passed to the Crown as bona vacantia, it would have been quite unnecessary to engage in such extraordinary intellectual contortions to reach the obvious conclusion.

(5) The fifth point in the judgment turned on whether, for the purposes of the Landlord and Tenant Act 1987, the Crown had an interest in the land following disclaimer of the freehold, even though it had not entered upon that land nor exercised any power of ownership over it. If the Crown did have such an interest, the sale by the mortgagee to the defendant would not have been one that triggered the tenants' right to nominate a purchaser to whom the defendant had to sell the land under the provisions of the 1987 Act. Having regard to the mischief of the Act, Deputy Judge Burnton held that what the Crown had on disclaimer did not amount to an interest for the purposes of that Act. As a result, the defendant had to sell the land to the tenants' nominee.

The second case is the decision of Knox J in Hackney $L B C_{V}$ Crown Estate Commissioners (1995) 72 P \& CR 233. The case concerned a Grade II listed Georgian property in Stoke Newington Church Street, which was left in a derelict state by its owner, a Mr Rottenberg. The property was subject to a mortgage of some $£ 133,000$ in favour of the National Westminster Bank, and there were charges in favour of Hackney Council under various regulatory statutes, such as the Prevention of Damage by Pests Act 1947 and the London Building Acts, which totalled some $£ 14,000$. The value of the property was reckoned to be a mere $£ 10,000$. Mr Rottenberg had been adjudicated bankrupt and his trustee in bankruptcy had disclaimed the freehold. The property had therefore escheated to the Crown, which was deliberately taking no action in relation to the property to ensure that it was not saddled with its liabilities. Nor was the National Westminster Bank taking any steps to enforce its mortgage. Under the Insolvency Act 1986, when a trustee in bankruptcy disclaims, it is open to a person with an interest in the property to apply to have the property vested in him, and the court can make such order as it thinks fit for such vesting. Hackney Council applied to the court for such an order and one which would exclude both the Crown Estate and the National Westminster Bank from any interest in the property. The case turned on whether the charges, which the Council had under the various regulatory statutes, gave it a sufficient interest to make such an application. Knox J held that they did and, in view of the passive attitude adopted by the Crown and the Bank, made the vesting order requested. Knox J gave his judgment on the assumption that, on escheat, Mr Rottenberg's freehold had vested in the Crown and that the Crown still had that freehold. It was that estate which he ordered to be vested in the Council. Of course, as will be apparent from what has been said earlier in this article, that assumption was incorrect: Mr Rottenberg's freehold had actually terminated. The effect of Knox J's order was, in substance, therefore, to make an infeudatory grant of land from the Crown to Hackney. Its effect, in other words, was rather like the sale by the mortgagee in the Scmlla case.

\section{REFORM}

The present state of the law can be described rather charitably as nonsensical. In the present writer's personal view, the time has come to sweep away both escheat and the Crown's paramount lordship. Indeed this should be part of a much wider package of reforms to the law on land ownership and dealing by the Crown and the two Duchies. The mid-19th century legislation that governs the property dealings of the two Duchies (which are significant) is lamentably out of date and wholly inappropriate to a system of registered conveyancing that is likely to be conducted electronically in the very near future.

The reform proposed is that all the land that the Crown presently holds in right of its paramount lordship should for the futurc be held in fee simple. There would be no higher form of ownership and the Crown would then become bound by the statute Quia Emptores 1290 like everybody else. All forms of feudal disposition would be wholly void. In cases where property presently passes to the Crown by escheat, it would pass instead as bona vacantia. It would no longer be possible for the Treasury Solicitor to disclaim property received as bona vacantia. As the Crown would remain as a kind of legal 'dustbin' for unwanted property, it would be protected against claims in relation to any property received as bona vacantia provided that it neither took possession of the property nor exercised rights of ownership over it.

In some ways the practical effect of these changes would be more apparent than real. They would certainly solve the problems that exist in relation to land registration. Furthermore, although the outcome in both the Scmlla and Hackney cases would have been the same had these reforms been implemented, it would have been considerably easier to reach the desired answer. Such changes would also be very much in line with what is happening in Scotland under the Abolition of Feudal Tenure etc. (Scotland) Bill. Feudalism runs much deeper in Scotland than it does in England. However, that Bill will abolish it all, including the Crown's paramount rights. There will be those who suggest this is just a subtle form of republicanism that is intended to undermine the Crown's constitutional position. The Scottish Law Commission, in its 'Report on Abolition of the Feudal System', elegantly refuted this contention. It pointed out that the abolition of the feudal system of land tenure would have no effect on the Crown's prerogatives, and commented that:

\section{'... it would be illogical, inconsistent and artificial to retain the highest element in the feudal system of land tenure while abolishing the lower elements'.}

It is precisely that illogical, inconsistent and artificial position that has existed in England and Wales for many years and that has created the present anomalies. It is time that we too abolished the highest element in the feudal system of land tenure.
Charles Harpum

Law Commissioner for England and Wales; Fellow of Downing College, Cambridge 